\title{
Estimation of physicochemical characteristics and associated metal contamination risk in the Narmada River, India
}

\author{
Saurabh Mishra ${ }^{1,3}$, Amit Kumar ${ }^{2,4^{+}}$ \\ ${ }^{1}$ Hohai University, College of Environment, Nanjing, Jiangsu Province, 210098, China \\ ${ }^{2}$ Nanjing University of Information Science and Technology, School of Hydrology and Water Resources, Nanjing, Jiangsu Province, 210044, China \\ ${ }^{3}$ Department of polymer and process engineering, Indian Institute of Technology Roorkee, Saharanpur Campus, Saharanpur, Uttar Pradesh, 247001, India \\ ${ }^{4}$ Hohai University, College of hydrology and Water Resources, Nanjing, Jiangsu Province, 210098, China
}

\begin{abstract}
River Narmada is the fifth largest holy river of Madhya Pradesh (M.P) flowing in the central part of India. The river receives large quantity of untreated/partially treated wastewater enriched with heavy metals and supplementary toxic organic pollutants. This study aims to assess the water quality status in river Narmada using indices like comprehensive pollution index (CPI), heavy metal pollution index (HPI), risk assessment index (RAI) and cancer risk index (CRI), for human use. The presence of faecal coliform and high chemical oxygen demand $>20 \mathrm{mg} / \mathrm{L}$ indicates that the water is unsuitable for drinking purposes. The average CPI and HPI evaluated to be 1.98, and 1.35, respectively signifies the moderately polluted river water. Considerably, the RAI $>1$ and CRI $>1$ is obtained at all sampling locations that alarms the possible cancer risk to human if untreated river water is used. Principal component analysis of data confirmed pollution in the river from both natural and anthropogenic sources. The strongest Pearson correlation coefficient between $\mathrm{Cu}-\mathrm{Pb}(0.998)$ and $\mathrm{Zn}-\mathrm{Cu}(0.986)$ indicates the input of wastewater in the river probably from electroplating industries. The river water is unsuitable for human intake. It is required to control direct flow of wastewater in river to restore ecological health.
\end{abstract}

Keywords: Heavy metal, Narmada River, Risk, Water pollution

\section{Introduction}

Water is an essential natural resource, critically needed for the survival of living organisms on earth. The natural freshwater bodies (e.g., rivers, lakes, and wetlands) are the major source of water to fulfill the daily water demand for household, agriculture and industrial activities [1]. India is naturally gifted with holy rivers such as Ganga, Yamuna, Godawari, Cauvery, Narmada and many others, which are adorned with religious mythological tales, and worshiped in Indian culture [2, 3]. Among these Indian rivers, Narmada is the $5^{\text {th }}$ largest west flowing peninsular river in central India and a lifeline for $1 / 4^{\text {th }}$ of the country's population [4]. Most townships and industrial complexes have been established around the banks of Indian rivers [5, 6]. Rapid increase in human population, consequent urbanization, change in land use and land cover (LULC), excessive extraction of water, shrinkage of river width, and direct disposal of untreated wastewater has led to the deterioration of water quality (WQ) in river Narmada [7]. The input wastewater is enriched with a large number of organic and inorganic contaminants that cause severe biotic risk, influences biogeochemical cycle and deteriorating ecological health of the river $[8,9]$. Thus, the rejuvenation of river Narmada and the conservation of biotic diversity in the river basin has become a hot topic of research and attracting researchers all around the world. In this regard, the proposals to improvise WQ in river Narmada were prepared and implemented by the governing authority that targeted the treatment of wastewater before discharge and plantation of vegetation around the river basin [10]. Despite these remedial measures and involvement of governing bureaucracy, there is no significant improvement in WQ of river Narmada and diversity of its biota (e.g., flora and fauna). In the recent past, Sharma et al. [11] have investigated the physicochemical and bacteriological characteristics of water in river Narmada and reported the presence of coliform bacteria in polluted river water resulting in unsuitability for human consumption. Also, Gupta and
This is an Open Access article distributed under the terms of the Creative Commons Attribution Non-Commercial License (http://creativecommons.org/licenses/by-nc/3.0/) which permits unrestricted non-commercial use, distribution, and reproduction in any medium, provided the original work is properly cited.

Copyright (C) 2021 Korean Society of Environmental Engineers
Received December 26, 2019 Accepted March 20, 2020

${ }^{\dagger}$ Corresponding author

Email: amitkdah@nuist.edu.cn

Tel: +86-18362071057

ORCID: 0000-0002-6073-0860 
Chakrapani [12] have worked out the spatio-temporal distribution of water flow and sediment load in Narmada basin, and reported that $\sim 85-95 \%$ of annual rainfall is the source of water in the river with the same percentage of sediment load. A few review articles are available in the literature that focused on physicochemical characteristics of water in river Narmada [13], as well causes of water pollution and human health risk [14], suggesting the presence of water-borne diseases in the river basin, which is one of the foremost cause of fatalities worldwide. Thus, a strict and vigilant approach towards WQ monitoring and assessment of river Narmada is needed to ensure its good ecological health.

Considerably, in most of the reported studies [15], the WQ status of river Narmada has been classified on the basis of the comparative judgment of individual WQ parameters to their standards defined in regional and international scale. But, these studies do not provide a complete picture or scenario of overall river water pollution or ecological health of a river. Moreover, a comprehensive study of WQ in the river Narmada involving assessment of heavy metals and other physicochemical parameters with biological characteristics that address the biotic risk is yet to be investigated. In the present study, physicochemical parameters (like DO, BOD, COD and others), heavy metals (like As, $\mathrm{Cu}, \mathrm{Cd}$ and others) concentration and bacteriological characteristics of water in river Narmada along the stretch in state Madhya Pradesh (M.P), India has been carried out extensively. It was focused to classify the suitability of river water for human use and identify the major pollutants present in the river. Globally, several water quality indices (WQI) have been developed for monitoring the surface WQ of freshwater bodies with respect to human use [16, 17]. WQI is a concise and comprehensive method that expresses the river WQ or pollution status in a single number by aggregating the values of different physicochemical parameters [18]. The WQI such as national sanitation foundation water quality indices (NSFWQI), comprehensive pollution index (CPI) and heavy metal pollution index (HPI) are proved to be trustworthy and most commonly used to classify the surface WQ [19]. In this study, the estimated data on the physicochemical parameters data were used to evaluate CPI, while the heavy metal concentration data were used to evaluate HPI for the respective sampling locations in river Narmada. Moreover, risk assessment index (RAI) and cancer risk index (CRI) [20-22] was evaluated to predict the possibilities of carcinogenic impact on human due to direct drinking of river water. Furthermore, environmetrics which involves multivariate statistical methods like principal component analysis (PCA) and hierarchical cluster analysis (HCA) $[23,24]$ was used to develop a composite indicator from the entire heavy metal datasets, and to identify the probable sources that significantly affect river WQ in the area under study.

\section{Material and Methods}

\subsection{Details of the Study Area}

River Narmada is the largest west flowing peninsular perennial river in central part of India. It originates from Maikala Hills near Amarkantakin Anuppur District of M.P flowing through Deccan traps towards western direction, and hemmed between Satpura and Vindhyan hills [15]. It covers a total length of 1,312 km through the state of M.P, draining total area of $98,796 \mathrm{~km}^{2}$ before merging with the Arabian Sea via the Gulf of Cambay near Bharuch city of Gujarat [11]. River Narmada basin lies from latitudes $21^{\circ} 20^{\prime} \mathrm{N}$ to $23^{\circ} 45^{\prime} \mathrm{N}$ and longitudes $72^{\circ} 32^{\prime} \mathrm{E}$ to $81^{\circ} 45^{\prime} \mathrm{E}$, and it is characterized by humid tropical climatic condition with an average $1,178 \mathrm{~mm}$ of annual rainfall. This river is joined by 41 tributaries (19 on the right bank and 22 are on the left bank), of which Banjar, HiranTawa, Burhner, Kundi, Chota-Tawa, and Orsang rivers are the major tributaries [12]. Considerably, river Narmada is a lifeline of Madhya Pradesh, draining the major land area of $85,938 \mathrm{~km}^{2}$ ( $\sim 87 \%$ of total river basin area) from east to west boundary of the state. Considering the entrance of drains, tributaries, and land-use pattern, the surface water samples were collected from selected 23 different sampling locations (Amarkantak to Koteshwar) for assessment of water pollution in the river Narmada. The step to step procedure followed to carry out this study has been represented in a flow chart, shown in Fig. 1(a). The details of all water sampling locations are shown in Table S1 of supplementary information (SI) and their locations are shown in Fig. 1(b), produced through ArcGIS 10.1 software.

\subsection{Sample Collection and Analysis}

At each sampling location, the subsurface water samples were collected from the shore side of river Narmada during winter season from November 2017 to March 2018. The samples were collected during the day time between 10:00 am to 11:00am at each sampling location. The collected composite water samples were filled in airtight acid rinsed plastic containers of $500 \mathrm{~mL}$ capacity and stored at $4^{\circ} \mathrm{C}$ without freezing to avoid unpredictable changes before analysis. Three containers were filled with water samples at each location, of which, one sample was fixed in biochemical oxygen demand (BOD) bottles for the analysis of $\mathrm{BOD}_{5}$, while two sample containers (in which no fixing reagents were added) were used for the analysis of other WQ parameters. It is to be noted that the parameters like surface water temperature (WT), dissolved oxygen (DO), pH and electrical conductivity (EC) were analysed at sampling sites using portable analytical instruments, shown in Table S2 of SI. The collected water samples were transported to the laboratory within $24 \mathrm{~h}$ for further analysis. The analysis of each parameter was carried out through an experimental procedure demonstrated as per APHA [25].The experimental procedure for analysis of WQ parameters with their abbreviation, measurement unit and standard acceptable limit in drinking water (prescribed as per BIS [26] and WHO [27]), shown in Table S2 of SI. Each experiment was carried out in a replicate of three and mean value of observations were considered to avoid the uncertainty.

\subsection{Water Quality Indices (WQI)}

In this study, the WQI like CPI, HPI, RAI and CRI were used to analyse the overall status of water quality in river Narmada. The indices are elaborately described as follow:

NSFWQI: It is the most commonly used WQI for the classification of WQ status in freshwater bodies around the world [19]. It involves parameters like DO, WT, pH, BOD, faecal coliform, total solid (TS) and turbidity. The mathematical equation (Eq. (1)) used to evaluate NSFWQI is expressed as:

$$
\text { NSFWQI }=\sum_{\mathrm{i}=1}^{\mathrm{p}} \mathrm{W}_{\mathrm{i}} \mathrm{I}_{\mathrm{i}}
$$



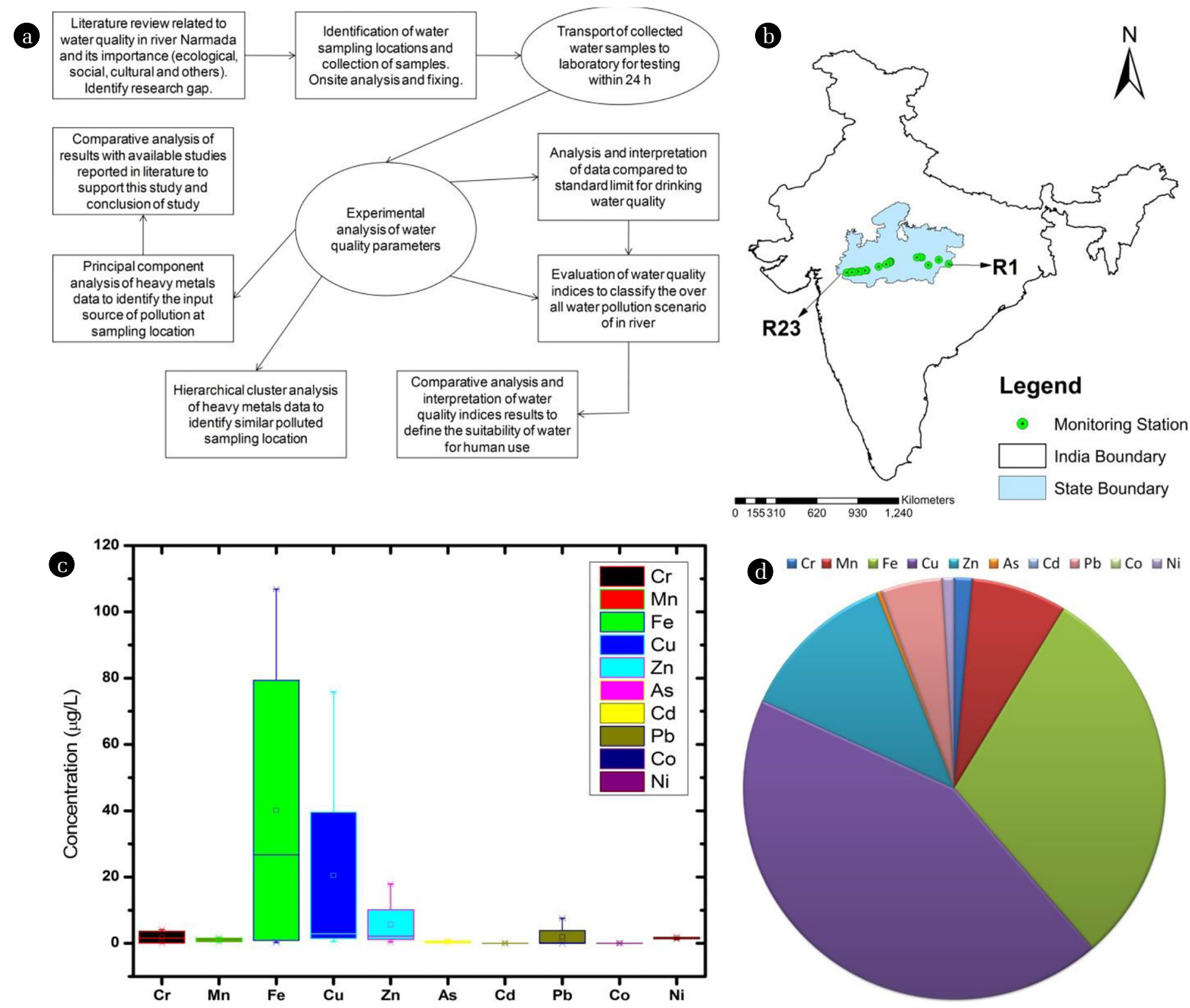

Fig. 1. Assessment of water quality in river Narmada: (a) Schematic diagram of the research methodology; (b) Sampling locations in river Narmada in state Madhya Pradesh, India; (c) Box and whiskers plot of variation and spatial distribution of heavy metals; (d) Pie plot representing abundance of heavy metals in the river.

where $\mathrm{W}_{\mathrm{i}}$ is the weightage factor of the $\mathrm{i}^{\text {th }} \mathrm{WQ}$ parameter, $\mathrm{p}$ is the total number of parameters and $I_{i}$ is the sub-index value of the $\mathrm{i}^{\text {th }}$ parameter. The WQ status at sampling locations along river Narmada is classified by NSFWQI value in range from 0-100: that is, 0-25 (very poor quality); 25-50 (poor quality); 50-70 (medium quality); 70-90 (good quality); and 90-100 (excellent quality).

CPI: It is based on parameters (like DO, pH, BOD, EC, COD, alkalinity, turbidity, total dissolved solids (TDS), total hardness (TH) and chloride) whose standard acceptable concentration limits (SAL) in drinking water have been prescribed as per BIS [26] and WHO [27]. It has been proved to be a trustworthy method for meaningful classification of the overall WQ status in a freshwater body [28]. The mathematical equations (Eq. (2) and (3)) used to evaluate CPI are expressed below:

$$
\mathrm{PI}_{\mathrm{i}}=\frac{\mathrm{C}_{\mathrm{i}}}{\mathrm{S}_{\mathrm{i}}}
$$

$$
\mathrm{CPI}=\frac{1}{\mathrm{n}} \sum_{\mathrm{i}=1}^{\mathrm{n}} \mathrm{PI}
$$

where PI is the sub pollution index of $i^{\text {th }}$ parameter, $S_{i}$ is the SAL of $i^{\text {th }}$ parameter in drinking water, $\mathrm{C}_{\mathrm{i}}$ is the analyzed concentration value of the $i^{\text {th }}$ parameter, and $n$ is the total number of parameters. The WQ status could be classified by CPI value in range from 0-2 as: 0-0.20 (excellent quality); 0.21-0.4 (good quality); 0.41-1.00 (slightly polluted quality); 1.01-2 (moderately polluted quality); $\geq 2.01$ (severely polluted quality).

HPI: It is widely used to estimate heavy metal contamination in a water body. HPI is evaluated on the basis of heavy metals whose SAL in drinking water has been prescribed as per BIS [26] and WHO [27]. It is a single factor index that classifies the water contamination and degree of toxicity contributed by heavy metals in a water body [19, 29]. The mathematical equations (Eq. (4) and (5)) used to evaluate HPI are expressed below: 


$$
\begin{gathered}
\mathrm{MI}=\sum_{\mathrm{i}=1}^{\mathrm{n}} \mathrm{C}_{\mathrm{i}} / \mathrm{S}_{\mathrm{i}} \\
\mathrm{HPI}=\sqrt{ }\left(\frac{1}{2}\left(\mathrm{MI}_{\max }^{2}+\mathrm{MI}_{\text {average }}^{2}\right)\right)
\end{gathered}
$$

where MI is the sub-index of $i^{\text {th }}$ heavy metal, $S_{i}$ is SAL of $i^{\text {th }}$ metal, and $C_{i}$ is the concentration of $i^{\text {th }}$ heavy metal. The heavy metal contamination in water could be classified by HPI value in range from 0-3 as: HPI $\leq 1$ (slightly contaminated water); 1-2 (contaminated water); 2-3: (moderately contaminated water); and HPI $\geq 3$ (severely contaminated water).

RAI: RAI is commonly used to estimate the probable occurrence of human health risk over a particular time period on exposure to the hazardous chemicals whose reference dose (RFD) is prescribed in RAIS database [30]. According to Lee et al. [31], the health risk assessment involves identification of pollutants, rate of pollutant exposure, toxicity response dose of pollutant, and characterization of biotic risk due to the pollutant. In this study, RAI was evaluated by using the concentration data of all heavy metals for the respective sampling locations. The RAI value can be evaluated by the following mathematical equations (Eq. (6), (7) and (8)) as:

$$
\begin{gathered}
\mathrm{ADD}_{\mathrm{i}}=\left(\mathrm{C}_{\mathrm{i}} \times \mathrm{IR} \times \mathrm{ED} \times \mathrm{EF}\right) /(\mathrm{BW} \times \mathrm{AT}) \\
\mathrm{HQ}_{\mathrm{i}}=\mathrm{ADD}_{\mathrm{i}} / \mathrm{RFD}_{\mathrm{i}} \\
\mathrm{RAI}=\sum_{\mathrm{i}=1}^{\mathrm{n}} \mathrm{HQ}_{\mathrm{i}}
\end{gathered}
$$

where ADD denotes average daily dose of the $i^{\text {th }}$ heavy metal and RFD reference dose of the $i^{\text {th }}$ heavy metal, $C_{i}$ is the analysed concentration value of the $\mathrm{i}^{\text {th }}$ heavy metal, $\mathrm{ED}$ denotes exposure duration, $\mathrm{EF}$ denotes exposure frequency, AT denotes average time, BW denotes human body weight, IR denotes ingestion rate and HQ is the sub-index of $i^{\text {th }}$ heavy metal. The RFD value (as per RAIS database) of manganese $(\mathrm{Mn})$, copper $(\mathrm{Cu})$, iron $(\mathrm{Fe})$, Chromium $(\mathrm{Cr})$, zinc (Zn), arsenic (As), cadmium (Cd), lead (Pb), cobalt (Co) and nickel (Ni) is shown in Table S3 of SI. RAI value can be classified into two categories where RAI $<1$ indicates acceptable carcinogenic risk and RAI $\geq 1$ indicates unacceptable carcinogenic risk. However, the risk of cancer means the probability of a human to develop cancer after exposure of contaminants to a given life period [32].

CRI: The probability of cancer risk is determined by oral slope factor (SFO) value of hazardous cancer-causing chemicals. In RAIS database, SFO value has been derived for $\mathrm{Cr}$, As, and $\mathrm{Pb}$, shown in Table S3 of SI. The cancer risk can be mathematically expressed as follows (Eq. (9)):

$$
\text { Cancer risk index }(\mathrm{CRI})=\mathrm{ADD}_{\mathrm{i}} \times \mathrm{SFO}
$$

The cancer risk values evaluated at a sampling location can be classified into two categories where value $\leq 1 \times 10^{-6}$ indicates acceptable level or very low risk of cancer, which means 1 person per 1,000,000, might be prone to cancer as a consequence of the exposure, while value $\geq 1 \times 10^{-6}$ indicates a high risk of cancer [20].

\subsection{Environmetrics Techniques}

The environmetrics statistical analysis of heavy metal concentration datasets was performed through HCA and PCA, using SPSS version 16.0 software. The HCA based on Ward method was used to develop the cluster of sampling locations that have similar pollution load. The PCA was used to classify the trend of metal contamination and to predict the input source of contamitants in the river.

\section{Results and Discussion}

The physicochemical and biological characteristics of water in river Narmada was assessed at 23 water sampling locations (R1-R23) during winter season (November 2017 to March 2018). The data on water quality parameters and heavy metals concentration, obtained during laboratory analysis of collected water samples at sampling locations (R1-R23) are shown in Table S4 and S5 of SI, respectively in terms of mean and standard deviation of triplicate observations. The analysed values of WT, TDS, and DO were obtained in range $21^{\circ} \mathrm{C}-26^{\circ} \mathrm{C}(\mathrm{R} 4), 24-442 \mathrm{mg} / \mathrm{L}$, and 5.7-8.5 mg/L, respectively at all sampling locations, which were found as per SAL. The $\mathrm{pH}$ values of water samples were obtained in range 7.1-8.8, which exhibit slightly alkaline water quality of river Narmada that could be due to the presence of carbonates and bicarbonates of magnesium and calcium in the water. The $\mathrm{pH}$ value was found within SAL (6.5-7.5) at locations R14, R15, R16, and R22, while it was found to be unacceptable ( $\mathrm{pH}$ value $>7.5$ ) at other locations. The EC value at locations R1, R2, R3, and R4 was obtained $>600$ $\mu \mathrm{S} / \mathrm{cm}$, which indicates the presence of salt and inorganic materials in the water. The maximum alkalinity concentration of $227 \mathrm{mg} / \mathrm{L}$ (> SAL $200 \mathrm{mg} / \mathrm{L}$ ) was found at location R16, while it was obtained within SAL at other locations, indicating the presence of carbonates, bicarbonates, and hydroxides in the water. High values of alkalinity might be due to excessive input of organic waste enriched wastewater from agricultural and domestic area [11]. Comparative analysis of TDS and TS concentration reveals that the locations R8, R12, R14, R16, and R19 are significantly affected by high load of suspended solids ( $>100 \mathrm{mg} / \mathrm{L}$ ) in the water. Considerably, the TH concentration was obtained as $310 \mathrm{mg} / \mathrm{L}, 400 \mathrm{mg} / \mathrm{L}, 340 \mathrm{mg} / \mathrm{L}$, and $400 \mathrm{mg} / \mathrm{L}$ at locations R12, R13, R16, and R17, respectively which is more than SAL, indicating the presence of chlorides, sulphates, and nitrates of calcium and magnesium in the water. However, the chloride concentration was obtained in range from $13-244 \mathrm{mg} / \mathrm{L}$ at all sampling locations, which is within the SAL. The variation in chloride concentration might be due to uncontrolled discharge of sewage and agricultural wastewater in the river Narmada. The turbidity of collected water samples was obtained in range 1.1-15 NTU (above SAL of 1 NTU) at all sampling locations. In another analysis, the BOD concentration was found to be acceptable at locations R15, R18, R19, R20, R21, and R23, while at other locations, it was more than SAL (5 mg/L), indicating high organic loading in the river. Consequently, the COD concentration was obtained as $9 \pm 0.01 \mathrm{mg} / \mathrm{L}$ and $13 \pm 0.01 \mathrm{mg} / \mathrm{L}$ at locations R21and R23, respectively which is acceptable as per SAL (20 mg/L COD), while at other locations, the higher concentration of COD $(>20$ $\mathrm{mg} / \mathrm{L}$ of SAL) indicates the heavy load of organic and inorganic pollutants. Moreover, as per BIS 2012, the faecal coliform should not be detected in $100 \mathrm{~mL}$ drinking water sample. In this study, 
the biological analysis of water samples indicates the presence of faecal coliform falling in the range of 1.1-8.9 MPN/100 mL (permissible faecal coliform $\leq 50$ ). In the available literature, Sharma et al. [11] have elaborately reported the physiochemical characteristic of water along the stretch of river Narmada and analysed the data through PCA technique. They have reported that the parameters like total alkalinity, COD, TDS, TH, and chloride of water in winter season varied in ranges from 26 to $71 \mathrm{mg} / \mathrm{L}, 5.1-13.4$ $\mathrm{mg} / \mathrm{L}, 698-1,585 \mathrm{mg} / \mathrm{L}, 70.25$ to $131.2 \mathrm{mg} / \mathrm{L}$, and 21.2 to $66 \mathrm{mg} / \mathrm{L}$, respectively. Compared to these reported data, the variation in concentration of these parameters has increased significantly in this study due to excessive input of wastewater in river Narmada, in recent past years. Based on the comparative analysis of these physicochemical and biological parameters to SAL, it is revealed that the WQ of river Narmada is not suitable for drinking purposes and requires prior treatment for further use.

The heavy metal concentration was investigated in the collected water samples at all sampling locations. Compared to SAL, the concentration of $\mathrm{Cu}$ was found to be higher (> $50 \mu \mathrm{g} / \mathrm{L} \mathrm{SAL}$ ) at locations R1 to R11, Pb was found to be higher ( $>10 \mu \mathrm{g} / \mathrm{L} \mathrm{SAL}$ ) at R1 to R4, and Mn was found to be higher ( $>100 \mu \mathrm{g} / \mathrm{L} \mathrm{SAL}$ ) at R23, while other heavy metals were found within their SAL at all sampling locations. The major heavy metal contamination was observed at the initial sampling locations (R1-R10), which lies in the industrial zone of M.P. The heavy metal concentration data obtained at all sampling locations were used to evaluate their mean and median value of data that represent the overall metal concentration in river Narmada along the stretch of M.P. The variation in data of heavy metals at the overall sampling locations is represented as box and whiskers plot shown in Fig. 1(c). Although, Fe concentration in the river water is found within SAL, it is due to variation in $\mathrm{Fe}$ concentration from various natural sources (i.e., runoff from weathering rock area in the catchments). Considerably, there is variation in concentration of $\mathrm{Cu}, \mathrm{Zn}$, and $\mathrm{Pb}$, which indicates the input of untreated industrial wastewater in the river while other metals are close to their mean value. The comparative analysis of its concentration in the river reveals that $\mathrm{Cu}$ is the most abundant heavy metal found, followed by others- $\mathrm{Fe}>\mathrm{Zn}>\mathrm{Mn}>\mathrm{Pb}>$ $\mathrm{Cr}>\mathrm{Ni}>\mathrm{As}>\mathrm{Cd}>\mathrm{Co}$ (Fig. 1(d)). Based on the above analysis, it was found that the river water is in the polluted categories and therefore, it is not suitable for drinking as per BIS [26] and WHO [27] water quality standard. However, to draw meaningful information, it is required to classify the overall water pollution status at respective sampling locations in the river.

\subsection{Water Quality Index Results}

In this study, the indices like NSFWQI, CPI, and HPI are evaluated to classify the status of water pollution at the sampling locations in river Narmada, the indices data are shown in Table 1. The NSFWQI result reveals that the water pollution at sampling location (R1-R4, R6-R8, R13, R16, R17, and R23) falls under medium range (50-70), while it is good at other locations. Although, NSFWQI

Table 1. Evaluation of Water Quality Indices and Risk Assessment Index at Sampling Location in River Narmada

\begin{tabular}{|c|c|c|c|c|c|c|c|c|}
\hline \multirow{2}{*}{$\begin{array}{l}\text { Sampling } \\
\text { location }\end{array}$} & \multicolumn{2}{|c|}{ NSFWQI } & \multicolumn{2}{|c|}{ CPI } & \multicolumn{2}{|r|}{ HPI } & \multicolumn{2}{|r|}{ RAI } \\
\hline & Value & Status & Value & Status & Value & Status & Value & Status \\
\hline $\mathrm{R} 1$ & 65 & Medium & 7.52 & Severely & 4.98 & Severely & 6.90 & Unacceptable \\
\hline $\mathrm{R} 2$ & 69 & Medium & 2.69 & Severely & 5.48 & Severely & 7.31 & Unacceptable \\
\hline R3 & 65 & Medium & 2.87 & Severely & 5.28 & Severely & 7.97 & Unacceptable \\
\hline R4 & 65 & Medium & 2.81 & Severely & 3.71 & Severely & 5.25 & Unacceptable \\
\hline R5 & 72 & Good & 1.51 & Moderately & 1.08 & Contaminated & 1.95 & Unacceptable \\
\hline R6 & 67 & Medium & 2.17 & Severely & 1.27 & Contaminated & 2.25 & Unacceptable \\
\hline R7 & 68 & Medium & 0.97 & Slightly & 1.10 & Contaminated & 2.00 & Unacceptable \\
\hline R8 & 69 & Medium & 2.01 & Severely & 0.94 & Slightly & 1.82 & Unacceptable \\
\hline R9 & 74 & Good & 1.01 & Moderately & 0.71 & Slightly & 1.57 & Unacceptable \\
\hline R10 & 74 & Good & 1.76 & Moderately & 1.05 & Contaminated & 1.87 & Unacceptable \\
\hline R11 & 70 & Good & 1.37 & Moderately & 0.69 & Slightly & 1.73 & Unacceptable \\
\hline R12 & 71 & Good & 1.81 & Moderately & 0.28 & Slightly & 6.18 & Unacceptable \\
\hline R13 & 69 & Medium & 2.66 & Severely & 0.30 & Slightly & 4.62 & Unacceptable \\
\hline R14 & 71 & Good & 2.55 & Severely & 0.25 & Slightly & 4.40 & Unacceptable \\
\hline R15 & 76 & Good & 1.88 & Moderately & 0.27 & Slightly & 4.05 & Unacceptable \\
\hline R16 & 64 & Medium & 1.71 & Moderately & 0.27 & Slightly & 3.26 & Unacceptable \\
\hline $\mathrm{R} 17$ & 69 & Medium & 1.86 & Moderately & 0.25 & Slightly & 3.20 & Unacceptable \\
\hline R18 & 74 & Good & 1.41 & Moderately & 0.13 & Slightly & 2.27 & Unacceptable \\
\hline R19 & 77 & Good & 0.76 & Slightly & 0.20 & Slightly & 2.24 & Unacceptable \\
\hline R20 & 80 & Good & 0.68 & Slightly & 0.18 & Slightly & 2.14 & Unacceptable \\
\hline R21 & 73 & Good & 1.50 & Moderately & 0.30 & Slightly & 2.65 & Unacceptable \\
\hline R22 & 72 & Good & 0.89 & Slightly & 0.21 & Slightly & 2.56 & Unacceptable \\
\hline R23 & 64 & Medium & 1.22 & Moderately & 2.02 & Moderately & 10.82 & Unacceptable \\
\hline
\end{tabular}



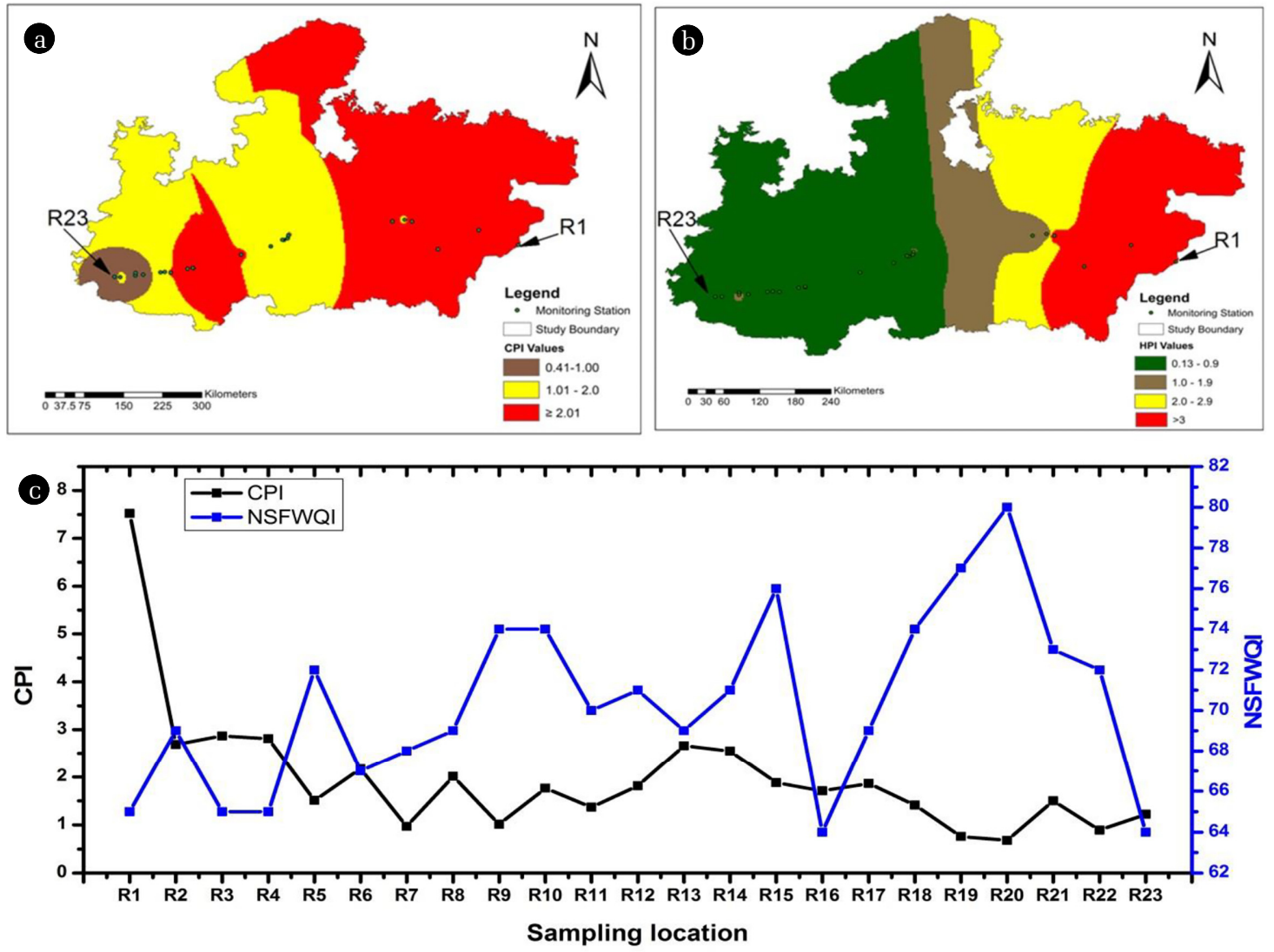

Fig. 2. Water quality status: (a) CPI based water quality status in river Narmada; (b) Trend analysis of heavy metal contamination in river Narmada; (c) Variations of NSFWQI and CPI at the sampling locations in river Narmada.

is evaluated on the basis of limited WQ parameters, thus it gives a predictable status of WQ [19]. Further, it is to be noted that there is no single standard WQI reported yet, which could be universally applied to assess the WQ in a water body. In the recent trend, the CPI is one of the most trustworthy acceptable WQI commonly used to classify the accurate water pollution status in a water body, which is based on SAL value of physicochemical parameters [28]. The CPI was evaluated at all sampling locations, which indicates severely polluted water quality at sampling locations R1-R4, R6-R8, R13 and R14, moderately polluted water quality at R5, R9-R12, R15-R18, R21 and R23, while slightly polluted water quality at the other locations, as shown in Fig. 2(a). The average CPI value of 1.98 was evaluated for water quality in river Narmada, which indicates the moderately polluted water quality that is not suitable for drinking purposes. Among all sampling locations, the highest CPI value of 7.52 was evaluated at location R1 (origin site of the river), which was found to be most affected due to heavy load of pollutants. River Narmada receives more pollution load near its origin, which considerably degrades the natural quality of water. The comparative analysis of NSFWQI and CPI results reveals almost similar trend in variation of WQ at all sampling locations (Fig. 2(c)). Thus, NSFWQI and CPI could be used to predict satisfactory and acceptable WQ trends in a water body. However, both indices do not involve the concen- tration data of heavy metals to classify the metal contamination in a water body [28].

To assess the heavy metal contamination in the water of river Narmada, HPI was evaluated using heavy metal concentration data obtained during laboratory analysis and their respective SAL value. The water quality at sampling locations R1-R4 was found to be severely contaminated (HPI value $>3$ ) due to heavy metals, which reveals that it is not suitable for drinking purposes as shown in Fig. 2(b). However, the metal contamination in the river decreases towards the downstream sampling locations from contaminated (R5-R7) to slightly contaminated (R11-R22) status, which might be due to sedimentation of metals and reduced input of metal carrying wastewater in the river. Also, the sampling locations R11-R22 lies in the forest cover area, which supports the bioaccumulation of heavy metals, and thus reduces metal contamination [12]. The water quality at sampling location R23 lies in mining area and is found to be moderately contaminated, which could be due to its geomorphologic location and high input of $\mathrm{Fe}$ and $\mathrm{Mn}$ carrying runoff entering the river from surrounding rock weathering areas [33]. The average NSFWQI, CPI, and HPI values of river Narmada were evaluated to be $70.35,1.98$, and 1.35 respectively, which reveals that the river water is moderately polluted and not suitable for drinking purposes. Moreover, due to the presence of toxic heavy metals in the river water, RAI was 
Table 2. Evaluation of Cancer Risk Value at Sampling Location in River Narmada

\begin{tabular}{lccccc}
\hline Sampling & \multicolumn{4}{c}{ Cancer risk value $\mathbf{( 1 \times 1 0 - 6 )}$} & Cancer risk \\
\cline { 2 - 5 } location & Cr & As & Pb & Average & status \\
\hline R1 & 317.44 & 2333.14 & 1943.07 & 1531.22 & High \\
R2 & 400.29 & 2090.83 & 2307.01 & 1599.37 & High \\
R3 & 790.48 & 3938.45 & 2144.09 & 2291.01 & High \\
R4 & 335.26 & 2365.21 & 1544.88 & 1415.12 & High \\
R5 & 594.49 & 2058.76 & 300.69 & 984.65 & High \\
R6 & 302.59 & 2238.71 & 464.99 & 1002.09 & High \\
R7 & 103.64 & 2195.95 & 380.15 & 893.24 & High \\
R8 & 603.40 & 1995.51 & 306.74 & 968.55 & High \\
R9 & 163.03 & 2423.11 & 191.07 & 925.74 & High \\
R10 & 333.48 & 1752.30 & 383.29 & 823.02 & High \\
R11 & 408.01 & 2432.02 & 206.62 & 1015.55 & High \\
R12 & 21736.75 & 15821.50 & 11.91 & 12523.39 & High \\
R13 & 21787.23 & 10512.04 & 8.48 & 10769.25 & High \\
R14 & 21427.92 & 10182.42 & 4.24 & 10538.19 & High \\
R15 & 20195.58 & 9175.76 & 5.20 & 9792.18 & High \\
R16 & 15064.28 & 7714.76 & 3.89 & 7594.31 & High \\
R17 & 13831.94 & 7509.87 & 2.68 & 7114.83 & High \\
R18 & 10488.28 & 4908.59 & 3.53 & 5133.47 & High \\
R19 & 11108.91 & 4890.77 & 3.38 & 5334.35 & High \\
R20 & 9710.27 & 4970.95 & 4.04 & 4895.08 & High \\
R21 & 9365.81 & 6877.37 & 2.47 & 5415.22 & High \\
R22 & 9529.13 & 6619.02 & 3.94 & 5384.03 & High \\
R23 & 10360.59 & 8195.82 & 0.81 & 6185.74 & High \\
\hline & & & & & \\
\hline
\end{tabular}

evaluated to assess the biotic risk to human health if water is used for drinking purposes. The RAI is based on RFD (obtained from RAIS database) and ADD values of heavy metals, which was evaluated on basis of heavy metal concentration data obtained during laboratory analysis of the water samples at all sampling locations shown in Table 2. The RAI result indicates an unacceptable biotic risk or cancer risk to human health if water is lifelong regularly used for drinking purposes in the vicinity of the river stretch without prior treatment. Furthermore, the occurrence of cancer risk to human health was verified by the evaluation of cancer risk value, which was based on $\mathrm{ADD}$ and $\mathrm{SFO}$ value of heavy metals. In this study, the SFO value of $\mathrm{Cr}$, As, and $\mathrm{Pb}$ were found in the RAIS database. Considerably, a cancer risk value $>1 \times 10^{-6}$ was obtained at all sampling locations shown in Table 2, which indicates the certainty of cancer risk to human health.

\subsection{Hierarchical Cluster Analysis Result}

The clustering of water sampling locations on the basis of similarity and dissimilarity of heavy metal contamination was carried out using HCA through Ward method based on the dataset of heavy metals obtained during laboratory analysis. In this study, the agglomeration schedule in HCA gained two clusters, which is represented as dendrogram in Fig. 3(a). The cluster 1 contains sampling locations R1, R2, R5, R9, R13, R12, R14, R15, R18, and R19, while cluster 2 contains other sampling locations. Considerably, the sampling
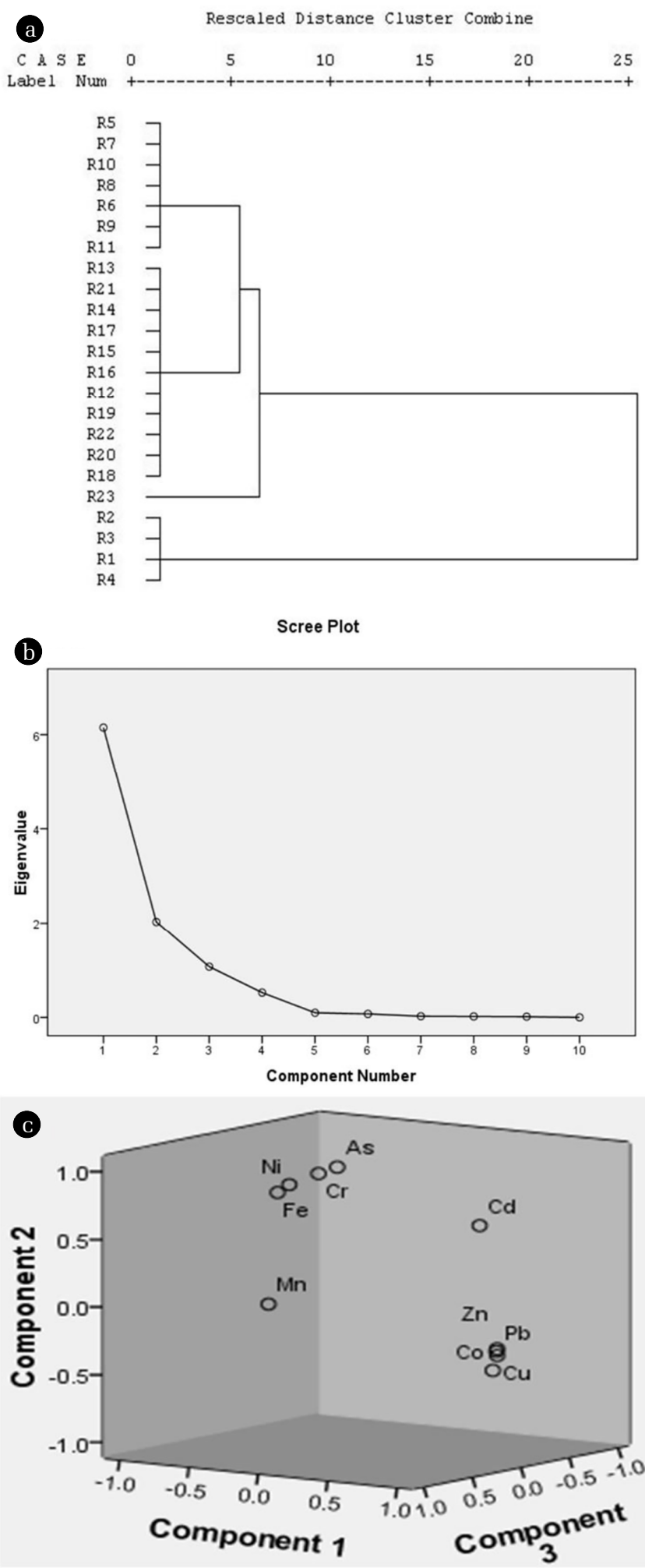

Fig. 3. HCA and PCA of heavy metal dataset: (a) Dendrogram of heavy metal contamination at sampling location using Ward method; (b) Scree plot of components; (c) Component loadings and score plot of heavy metals. 
locations R15, R19, R12, and R5 were found in both clusters, which could be due to the impact of their geomorphologic position and heavy metal input from both point and no-point sources. The first cluster signifies the input of heavy metals in the river water mainly from the anthropogenic sources, while cluster two indicates the heavy metal contamination due to both anthropogenic and natural sources [19]. Most of the sampling locations of downstream regions were grouped in second cluster that confirms the input of heavy metals through runoff from forest cover and agricultural area.

\subsection{Inter-Metal Relationships in River Narmada}

In order to classify the pathway and input source of heavy metals in the river water, Pearson correlation coefficient analysis was performed using heavy metal concentration data shown in Table 3. It can be clearly observed that the $\mathrm{Cu}$ has strongest correlation coefficient with $\mathrm{Pb}$ and $\mathrm{Zn}$ to be 0.998 , and 0.986 respectively, which indicate the input of wastewater from electroplating industries [8, 34]. The strong positive correlation coefficient between $\mathrm{Cr}$-As of 0.932 , and Cr-Fe of 0.873 indicates the input of agricultural wastewater through runoff into the river. In addition, the $\mathrm{Cr}-\mathrm{Ni}$ has gained a strong positive correlation coefficient of 0.914 , which indicates the input of mining industrial wastewater into the river [35]. The heavy metal $\mathrm{Mn}$ has strong correlation with Fe, As, and $\mathrm{Ni}$ of $0.4,0.163$, and 0.0198 respectively, which confirms its input in the river from natural mining sites and mountainous agricultural runoff. River Narmada flows through basaltic rock mountainous region in the peninsular part of India [7]. Hence, the input of $\mathrm{Cr}, \mathrm{Mn}$ and Fe are commonly added to the river water through runoff from those mountainous areas. These heavy metals are commonly extracted from their ores in mountainous regions [35]. The strong positive correlation between $\mathrm{Zn}-\mathrm{Pb}$, and $\mathrm{Zn}$-Co of 0.981 , and 0.842 , respectively indicates their input source as runoff sediment from natural rock weathering areas. The positive correlation coefficient of 0.462 is found between Cd-As, which are common heavy metals used by fertilizer industries, which give rise to the input of agricultural runoff into the river. The positive correlation coefficient between heavy metals demonstrates their actual characteristics, mutual dependency and common input source. Moreover, it is revealed that the river Narmada receives metal-contaminated wastewater from both anthropogenic and natural sources.

\subsection{Principal Component Analysis Result}

To validate the relationship between heavy metals, in order to extract trustworthy information and to ensure their input source, PCA was carried out using heavy metal concentration data through varimax normalized rotation method. Primarily, in order to estimate the number of components during PCA, scree plot of heavy metal datasets was constructed, as shown in Fig. 3(b). From the scree plot, the major break could be observed after the second component, which indicates that the first two components could produce more meaningful information [18]. The component eigen value curve in scree plot has dropped after the third component, which indicates that the third component might be useful for better interpretation of the datasets. Thereafter, Kaiser-Meyer-Olkin (KMO) and Bartlett's test of data was executed before performing the component analysis. The KMO sampling adequacy was obtained as 0.664 with Bartlett's test of sphericity (approx. Chi-Square:413.750; degree of freedom: 45 ; statistical significance: 0.0 ), which indicates the suitability of the datasets for PCA.

The PCA of heavy metal concentration data has gained three PCs, which are represented by loading and score plot as shown in Fig. 3(c). All the three PCs have eigen value $>1$ with a cumulative variance percentage of 92.490, as shown in Table 4. The PC1with variance of $61.5 \%$ has the highest positive loading of $\mathrm{Ni}$, Fe, As, and Mn, whereas PC 2 exhibits the positive loading of all heavy metals with a variance of $20.28 \%$. The positively loaded metals in PC1indicates their input source from both anthropogenic and natural sources, while positive loading of metals in PC2 indicates their input through direct discharge of untreated/partially treated wastewater from industrial activities or domestic sewage into the river [36]. In PC2, Cd exhibit the highest positive loading (0.862) followed by $\mathrm{As}>\mathrm{Zn}>\mathrm{Cr}>\mathrm{Pb}>\mathrm{Cu}$. It is generally believed that metals like $\mathrm{Cd}, \mathrm{Cu}, \mathrm{Cr}, \mathrm{As}$ and $\mathrm{Pb}$ enter in the river water mainly through industrial wastewater [22]. Considerably, Cd and $\mathrm{Cr}$ are commonly found in wastewater from petrochemical, metal smelting and pharmaceutical industries [8]. While metals like $\mathrm{Cu}, \mathrm{Zn}$ and $\mathrm{Pb}$ are commonly used in electroplating industries [22]. The metal As is commonly found in wastewater from agricultural area and fertilizer industries. The highest positive loading of $\mathrm{Mn}$ (0.943) was obtained in PC3 with a variance of $10.71 \%$, which indicates the input of metal carrying wastewater from parent material weathering and pedogenic process [37]. Moreover, the positive load of $\mathrm{Zn}$,

Table 3. Pearson Correlation Coefficients of Heavy Metals

\begin{tabular}{|c|c|c|c|c|c|c|c|c|c|c|}
\hline Heavy metals & $\mathrm{Cr}$ & Mn & Fe & $\mathbf{C u}$ & Zn & As & Cd & $\mathbf{P b}$ & Co & $\mathrm{Ni}$ \\
\hline $\mathrm{Cr}$ & 1.000 & & & & & & & & & \\
\hline $\mathrm{Mn}$ & 0.064 & 1.000 & & & & & & & & \\
\hline $\mathrm{Fe}$ & 0.873 & 0.400 & 1.000 & & & & & & & \\
\hline $\mathrm{Cu}$ & -0.584 & -0.134 & -0.590 & 1.000 & & & & & & \\
\hline Zn & -0.538 & -0.128 & -0.544 & 0.986 & 1.000 & & & & & \\
\hline As & 0.932 & 0.163 & 0.850 & -0.492 & -0.449 & 1.000 & & & & \\
\hline $\mathrm{Cd}$ & 0.225 & -0.122 & 0.047 & 0.314 & 0.335 & 0.462 & 1.000 & & & \\
\hline $\mathrm{Pb}$ & -0.554 & -0.124 & -0.555 & 0.998 & 0.981 & -0.463 & 0.323 & 1.000 & & \\
\hline Co & -0.710 & -0.157 & -0.736 & 0.870 & 0.842 & -0.591 & 0.345 & 0.853 & 1.000 & \\
\hline $\mathrm{Ni}$ & 0.914 & 0.198 & 0.955 & -0.642 & -0.593 & 0.868 & 0.071 & -0.608 & -0.781 & 1.000 \\
\hline
\end{tabular}


Table 4. PCA Components Values and Communalities of Heavy Metals

\begin{tabular}{lcccc}
\hline \multirow{2}{*}{ Elements } & \multicolumn{3}{c}{ Component } & Communalities \\
\cline { 2 - 5 } & $\mathbf{1}$ & $\mathbf{2}$ & $\mathbf{3}$ & \\
Initial Eigen values & 6.150 & 2.028 & 1.071 & \\
Variance \% & 61.498 & 20.281 & 10.712 & \\
Cumulative \% & 61.498 & 81.779 & 92.490 & \\
$\mathrm{Co}$ & -0.920 & 0.237 & 0.029 & 0.903 \\
$\mathrm{Ni}$ & 0.908 & 0.303 & 0.040 & 0.918 \\
$\mathrm{Cu}$ & -0.887 & 0.393 & 0.124 & 0.956 \\
$\mathrm{Fe}$ & 0.879 & 0.317 & 0.257 & 0.940 \\
$\mathrm{~Pb}$ & -0.865 & 0.418 & 0.134 & 0.941 \\
$\mathrm{Cr}$ & 0.862 & 0.421 & -0.122 & 0.936 \\
$\mathrm{Zn}$ & -0.854 & 0.432 & 0.127 & 0.932 \\
$\mathrm{As}$ & 0.795 & 0.587 & -0.049 & 0.978 \\
$\mathrm{Cd}$ & -0.101 & 0.862 & -0.216 & 0.800 \\
$\mathrm{Mn}$ & 0.235 & 0.007 & 0.943 & 0.944 \\
\hline
\end{tabular}

$\mathrm{Pb}$, and $\mathrm{Fe}$ in PC3 confirms the mining wastewater input into the river. Thus, the PCA result confirms the indication made during the analysis of Pearson correlation coefficient for input source of heavy metals.

The present study reveals that there is no improvement in the WQ of river Narmada in sampling years 2017-18, as the CPI value $>2$ (poor WQ) was obtained at most of the sampling locations. The river water is polluted due to input of untreated/partially treated wastewater from industrial and domestic sectors. The present result is supported by Gupta et al. [7], who reported the poor WQ in the river and its unsuitability for human consumption. Jain et al. [15] examined metal fractions on bed sediment of river Narmada and reported that the heavy metals (like $\mathrm{Mn}, \mathrm{Cu}, \mathrm{Ni}, \mathrm{Cr}, \mathrm{Pb}, \mathrm{Zn}$, and Cd) concentrations in sediments were higher than their standard shale values. They suggested that the anthropogenic activities, soil erosion, and agricultural runoff were the major sources of pollution in river Narmada. In the current scenario, the biotic risk due to imbalanced concentration of heavy metals in the river still exists as the HPI > 3 was obtained in this study at the sampling locations (R1, R2, R3, and R4) near the river origin. Hence, it is necessary to review the existing conservation plan so as to include the regular monitoring and treatment strategies for wastewater entering the river, which will improvise the assimilative capacity of the river.

A comparative analysis of average heavy metal concentration (estimated in this study) dissolved in river Narmada with the other Indian rivers average is incorporated in Table 5. Based on the analysis of heavy metals data (shown in Table 5), it is revealed that the average $\mathrm{Cu}$ concentration in river Narmada is higher than most of the Indian River's average except river Ganga, Sabarmati, and Damodar. While the estimated average concentration of other dissolved heavy metals in this study is comparatively lower than most of the Indian River's average. Although, heavy metal contamination in river Narmada is lower than average heavy metal concentration in other Indian rivers, present study reveals that the river water is moderately contaminated and not suitable for drinking purposes. Therefore, it is suggested that the remedial measures should be considered including prevention or strict control on discharge of untreated/partially treated wastewater in the river, proper treatment of industrial wastewater, regular monitoring of water quality, diversion of drains and constructing bunds or buffer strips to check agricultural runoff. This is to improvise the self-assimilative capacity and ecological health of river Narmada.

\section{Conclusions}

The physicochemical and biological characteristics of WQ in river Narmada have been assessed, considering 23 different sampling locations along the stretch of the river. The evaluation of overall water pollution status in the river was evaluated using NSFWQI, CPI and HPI. The average NSFWQI, CPI, and HPI of river were evaluated to be $70.35,1.98$, and 1.35 , respectively, which reveals that the river water falls under moderately polluted and it is not suitable for drinking purposes. Furthermore, the probability of cancer risk to human health on exposure to river water is evaluated

Table 5. Comparative Analysis of Average Heavy Metal Concentration Dissolved in the Indian Rivers

\begin{tabular}{|c|c|c|c|c|c|c|c|c|c|c|c|c|c|}
\hline S. No & Rivers name & Location & $\begin{array}{c}\text { Mn } \\
(\mu \mathrm{g} / \mathrm{L})\end{array}$ & $\begin{array}{c}\mathrm{Cu} \\
(\mu \mathrm{g} / \mathrm{L})\end{array}$ & $\begin{array}{c}\text { Co } \\
(\mu \mathrm{g} / \mathrm{L})\end{array}$ & $\begin{array}{c}\mathrm{Fe} \\
(\mu \mathrm{g} / \mathrm{L})\end{array}$ & $\begin{array}{c}\mathrm{Ni} \\
(\mu \mathrm{g} / \mathrm{L})\end{array}$ & $\begin{array}{c}\mathrm{Zn} \\
(\mu \mathrm{g} / \mathrm{L})\end{array}$ & $\begin{array}{c}\mathrm{Pb} \\
(\mu \mathrm{g} / \mathrm{L})\end{array}$ & $\begin{array}{c}\mathrm{Cr} \\
(\mu \mathrm{g} / \mathrm{L})\end{array}$ & $\begin{array}{c}\text { Cd } \\
(\mu \mathrm{g} / \mathrm{L})\end{array}$ & $\begin{array}{c}\text { As } \\
(\mu \mathrm{g} / \mathrm{L})\end{array}$ & Reference \\
\hline 1 & Ganga & Western Uttar Pradesh & $\mathrm{NR}$ & 1910 & $\mathrm{NR}$ & 2810 & $\mathrm{NR}$ & 2500 & $\mathrm{NR}$ & 550 & $\mathrm{NR}$ & $\mathrm{NR}$ & [28] \\
\hline 2 & Sabarmati & Gujarat & NR & 386 & NR & NR & 289 & 103 & NR & 309 & NR & NR & [38] \\
\hline 3 & Subarnarekha & West Bengal & 7.04 & 4.84 & 0.27 & 83.60 & 3.03 & NR & NR & 0.80 & NR & NR & [39] \\
\hline 4 & Mahanadi & State of Orissa & 17.51 & 9.86 & 5.81 & 113.50 & 13.12 & 23.21 & 7.31 & 5.13 & 1.23 & NR & {$[40]$} \\
\hline 5 & Achankovil & Kerala & 699 & 224 & $\mathrm{NR}$ & 11858 & $\mathrm{NR}$ & 415 & 72 & $\mathrm{NR}$ & 6 & NR & [41] \\
\hline 6 & Damodar & West Bengal & NR & 3950 & $\mathrm{NR}$ & 480 & NR & NR & NR & 11550 & 300 & NR & [42] \\
\hline 7 & Gomti & Uttar Pradesh & 97 & 1.30 & $\mathrm{NR}$ & 220 & 9 & 28.5 & 26 & 4 & 0.40 & NR & [43] \\
\hline 8 & Koel-Brahmani & West Bengal & 303.30 & 6.67 & 8.67 & 481 & 24.78 & 31.56 & 1.67 & 10.89 & $\mathrm{NR}$ & NR & [44] \\
\hline 9 & Hindon & Western Uttar Pradesh & 129 & 6.6 & NR & 226 & 24 & 58 & 37 & 15 & $\mathrm{NR}$ & NR & [45] \\
\hline 10 & Brahmani river & State of Orissa & 102 & 4.70 & 5.6 & 95 & 52 & 80.10 & 27 & NA & 4 & NR & {$[46]$} \\
\hline 11 & Baitarani & State of Orissa & 1.70 & 3.45 & 0.70 & 100.5 & 3.90 & 272.30 & 3.45 & 9.60 & NR & NR & [47] \\
\hline 12 & Kali (East) & Western Uttar Pradesh & NR & NR & NR & 1530 & $\mathrm{NR}$ & 24710 & 130 & 60 & 60 & NR & {$[48]$} \\
\hline 13 & Narmada & Madhya Pradesh & 13.68 & 80.80 & 0.05 & 55.95 & 1.68 & 22.77 & 8.81 & 2.62 & 0.06 & 0.6 & In this study \\
\hline
\end{tabular}


using RAI and CRI. Considerably, the RAI and CRI falling under less than one signify the high probability of cancer risk due to high concentration of copper $(\mathrm{Cu}>50 \mu \mathrm{g} / \mathrm{L})$, lead $(\mathrm{Pb}>10 \mu \mathrm{g} / \mathrm{L})$ and manganese $(\mathrm{Mn}>100 \mu \mathrm{g} / \mathrm{L})$. The relative abundance of average heavy metal concentration in the river was obtained to be $\mathrm{Cu}>$ $\mathrm{Fe}>\mathrm{Zn}>\mathrm{Mn}>\mathrm{Pb}>\mathrm{Cr}>\mathrm{Ni}>\mathrm{As}>\mathrm{Cd}>$ Co. Based on heavy metal contamination, all the sampling locations are obtained in two clusters during hierarchical cluster analysis. The metal relationship between $\mathrm{Cu}-\mathrm{Pb}$ and $\mathrm{Zn}-\mathrm{Cu}$ gained high Pearson correlation coefficient of 0.998, and 0.986, respectively, which indicates the input of metal carrying untreated/partially treated wastewater in the river from electroplating industries. Further, PCA gained three PCs and all the heavy metals were positively loaded in PC2 which confirmed their input in the river Narmada from natural and anthropogenic sources. Therefore, it is suggested that river water must be treated before used for drinking purposes to avoid unpredictable risks to human health. This study provides the future direction to the researchers, environmentalists and water resources planners and managers to take necessary action to maintain the aesthetic value of the rivers and further protract aquatic biodiversity.

\section{Acknowledgment}

The author are highly thankful to Amrish Kumar (DPPE, IITR, India) and Vivek Kumar (DPPE, ITTR, India) who helped in laboratory testing of water samples and provided raw data for further analysis.

\section{Author Contributions}

S.M. (Postdoc fellow) and A.K. (Associate Professor) generated the concept followed by discussion and article preparation. Both authors contributed equally in completing the article.

\section{References}

1. Eliku T, Leta S. Spatial and seasonal variation in physicochemical parameters and heavy metals in Awash River, Ethiopia. App. Water Sci. 2018;8:177.

2. Pradhan S, Kumar P, Mehrotra I. River pollution: Assessment of hydro-philic and phobic nature of persistent organic contaminants. Environ. Nanotech. Monit. Manag. 2015;3:47-54.

3. Sharma BM, Becanova J, Martin S, et al. Health and ecological risk assessment of emerging contaminants (pharmaceuticals, personal care products, and artificial sweeteners) in surface and groundwater (drinking water) in the Ganges River Basin, India. Sci. Total Environ. 2019;646:1459-1467.

4. Sharma S, Dixit S, Jain P, Shah KW, Vishwakarma R. Statistical evaluation of hydrobiological parameters of Narmada River water at Hoshangabad City, India. Environ. Monit. Assess. 2008;143:195-202.

5. Yadav NS, Sharma MP, Kumar A. Ecological Health Assessment of Chambal River, India. J. Mater. Env. Sci. 2015; 6(3):613-618.

6. Mishra S, Sharma MP, Kumar A. Pollution characteristic and health risk assessment of toxic chemicals of surface water in
Surha Lake, India. J. Mat. Environ. Sci. 2016b;7: 799-807.

7. Gupta N, Pandey P, Hussain J. Effect of physicochemical and biological parameters on the quality of river water of Narmada, Madhya Pradesh, India. Water Sci. 2017; 31:11-23.

8. Chen Q, Lu Z, Yan D, Qi W, Xin S. Source analysis and health risk of heavy metals in the different seasons from Taizihe River, China. Acta. Ecolo. Sinica. 2018;40:64-71.

9. Singh V, Sharma MP, Sharma S, Mishra S. Bio-assessment of River Ujh using benthic macro-invertebrates as bioindicators, India. Int. J. River Basin Manag. 2019;17:79-87.

10. Gour S, Jaloree S, Gour M. Water Quality Assessment using Association Rule Mining for River Narmada. Indian J. Sci. Tech. 2016;9:1-5.

11. Sharma A, Bora CR, Shukla V. Evaluation of Seasonal Changes in Physico-chemical and Bacteriological Characteristics of Water from the Narmada River (India) Using Multivariate Analysis. Nat. Resour. Res. 2013;22:283-296.

12. Gupta H, Chakrapani GJ. Temporal and spatial variations in water flow and sediment load in Narmada River Basin, India: natural and man-made factors. Environ. Geol. 2005;4-5:579-589.

13. Malviya P, Dwivedi AK. Physico-chemical parameters of Narmada River Water: A review. Int. J. Chem. Stud. 2015;3:1-4.

14. Katakwar M. Narmada river water: Pollution and its impact on the human health. Int. J. Chem. Stud. 2016;4:66-70.

15. Jain CK, Gupta H, Chakrapani GJ. Enrichment and fractionation of heavy metals in bed sediments of River Narmada, India. Environ. Monit. Assess. 2008;141:35-47.

16. Bilgin A. Evaluation of surface water quality by using Canadian Council of Ministers of the Environment Water Quality Index (CCME WQI) method and discriminant analysis method: a case study of Coruh River Basin. Environ. Monit. Assess. 2018;190: 554.

17. Zhang L. Big Data, Knowledge Mapping for Sustainable Development A Water Quality Index Case Study. Emerg. Sci. J. 2019;3:249-254.

18. Tripathi M, Singal SK. Use of Principal Component Analysis for parameter selection for development of a novel Water Quality Index: A case study of river Ganga India. Ecol. Indicat. 2019;96: 430-436.

19. Mishra S, Kumar A, Shukla P. Study of Water Quality in Hindon River Using Pollution Index and Environmetrics, India. Desalin. Water Treat. 2015;56(3):1-10.

20. Wongsasuluk P, Chotpantarat S, Siriwong W, Robson M. Heavy metal contamination and human health risk assessment in drinking water from shallow groundwater wells in an agricultural area in Ubon Ratchathani province, Thailand. Environ. Geochem. Health. 2014;36:169-182.

21. Singh KR, Dutta R, Kalamdhad AS, Kumar B. Risk characterization and surface water quality assessment of Manas River, Assam (India) with an emphasis on the TOPSIS method of multiobjective decision making. Environ. Earth Sci. 2018;77: 780-785.

22. Xiao J, Wang L, Deng L, Jin Z. Characteristics, sources, water quality and health risk assessment of trace elements in river water and well water in the Chinese Loess Plateau. Sci. Total Environ. 2019;650:2004-2012.

23. Yilma M, Kiflie Z, Windsperger A, Gessese N. Assessment and 
interpretation of river water quality in Little Akaki River using multivariate statistical techniques. Int. J. Environ. Sci. Tech. 2018;16:3707-3720.

24. Hamil S, Arab S, Chaffai A, Baha M, Arab A. Assessment of surface water quality using multivariate statistical analysis techniques: a case study from Ghrib dam, Algeria. Arab. J. Geosci. 2018;11:754-761.

25. American Public Health Association (APHA). AWWA and WPCF Standard Methods for the Examination of Waters and Waste Waters. 22 ${ }^{\text {nd }}$ ed. Washington DC; 2011.

26. Bureau of Indian Standards (BIS: 10500). Indian standard specification for drinking water. Second Revision. New Delhi; 2012.

27. Guidelines for drinking-water quality: fourth edition incorporating the first addendum. Geneva: World Health Organization (WHO); 2017. Licence: CC BY-NC-SA 3.0 IGO. ISBN 978-92-4154995-0.

28. Chaudhary M, Mishra S, Kumar A. Estimation of water pollution and probability of health risk due to imbalanced nutrients in River Ganga, India. Int. J. River Basin Manag. 2017;15:53-60.

29. Yang CL, Guo RP, Yue QL, Zhou K, Wu ZF. Environmental quality assessment and spatial pattern of potentially toxic elements in soils of Guangdong province, China. Environ. Earth Sci. 2013;70:1903-1910.

30. The Risk Assessment Information System. Chemical toxicity values (RAIS database) [cited 18 December 2018]. Available from: https://rais.ornl.gov/cgi-bin/tools/TOX search?select=chemmeta.

31. Lee JS, Chon HT, Kim KW. Human risk assessment of As, $\mathrm{Cd}, \mathrm{Cu}$ and $\mathrm{Zn}$ in the abandoned metal mine site. Environ. Geochem. Health. 2005;27:185-191.

32. Adamu CI, Nganje TN, Edet A. Heavy metal contamination and health risk assessment associated with abandoned barite mines in Cross River State, south eastern Nigeria. Environ. Nanotech. Monit. Manag. 2015;3:10-21.

33. Gupta H, Chakrapani GJ. Temporal and spatial variations in water flow and sediment load in the Narmada River. Current Sci. 2007;92:679-684.

34. Liu J, Zhang XH, Tran H, Wang DQ, Zhu YN. Heavy metal contamination and risk assessment in water, paddy soil, and rice around an electroplating plant. Environ. Sci. Poll. Res. 2011;18:1623-1632.

35. Qu B, Zhang Y, Kang S, Sillanpaa M. Water quality in the Tibetan Plateau: Major ions and trace elements in rivers of the "Water Tower of Asia". Sci. Total Environ. 2019;649:571-581.

36. Dutta S, Dwivedi A, Kumar MS. Use of water quality index and multivariate statistical techniques for the assessment of spatial variations in water quality of a small river. Environ. Monit. Assess. 2018;190:718-724.

37. Rajkumar H, Naik PK, Rishi MS. Evaluation of heavy metal contamination in soil using geochemical indexing approaches and Chemometric Techniques. Int. J. Environ. Sci. Tech. 2018;16:7467-7486.

38. Kumar RN, Solanki R, Kumar JIN. Seasonal variation in heavy metal contamination in water and sediments of river Sabarmati and Kharicut canal at Ahmedabad, Gujarat. Environ. Monit. Assess. 2013;185:359-368.

39. Giri S, Singh AK. Risk assessment, statistical source identification and seasonal fluctuation of dissolved metals in the Subarnarekha River, India. J. Hazard. Mat. 2014;265:305-314.

40. Sundaray SK, Nayak BB, Kanungo TK, Bhatta D. Dynamics and quantification of dissolved heavy metals in the Mahanadi river estuarine system, India. Environ. Monit. Assess. 2012;184: 1157-1179.

41. Prasad MBK, Ramanathan AL, Shrivastav SK, Anshumali, Sexena R. Metal fractionation studies in surfacial and core sediments in the Achankovil river basin in India. Environ. Monit. Assess. 2006;121:77-102.

42. Chatterjee SK, Bhattacharjee I, Chandra G. Water quality assessment near an industrial site of Damodar River. India. Environ. Monit. Assess. 2010;161:177-189.

43. Singh VK, Singh KP, Mohan D. Status of heavy metals in water and bed sediments of river Gomti - a tributary of the Ganga River, India. Environ. Monit. Assess. 2005;105:43-67.

44. Sundaray SK. Application of multivariate statistical techniques in hydrogeochemical studies - a case study: Brahmani-Koel River (India). Environ. Monit. Assess. 2010;164:297-310.

45. Jain CK, Sharma MK. Heavy metal transport in the Hindon river basin, India. Environ. Monit. Assess. 2006;112:255-270.

46. Reza R, Singh G. Heavy metal contamination and its indexing approach for river water. Intern. J. Environ. Sci. Technol. 2010;7:785-792.

47. Nayak BB, Panda UC, Panigrahy PK, Acharya BC. Dynamics of heavy metals in Dhamara Estuary of Orissa state in India. Chem. Environ. Res. 2001;10:203-218.

48. Mishra S, Kumar A, Yadav S, Singhal MK. Assessment of heavy metal contamination in water of Kali River using principle component and cluster analysis, India. Sustain. Water Resour. Manag. 2018;4:573-581.

49. EPA. US EPA Office of Water. Office of science and technology (EPA-822-R-00-001) [online]. Environmental Protection Agency Region I, Washington, DC 20460; 2004 [cited 18 December 2018]. Available from: www.epe.gov/safewater.

50. US EPA. Exposure Factor Handbook (EPA/600/p-95/002Fa) (Update to Expo-sure Factors Handbook EPA/600/8-89/043). Washington, DC: Environmental Protection Agency Region I; 1977. 